\title{
ACADEMIC QUESTIONS
}

\author{
RODERICK A MACDONALD*
}

\section{INTRODUCTION}

The paper which has been reproduced in your Conference Materials is, in many ways, a reflection of McLuhan's dictum that "the medium is the message". Consequently I should like to begin my presentation with a brief note on methodology. I start from three assumptions. First, I believe that we all speak best when we speak from experience, and that therefore, we ought always to attempt to hold that experience up for critical examination by others. Second, I believe that we all know a lot more about things than we can say when called upon to do so explicitly and in a scholarly format - in our practices, in our unstructured interactions, in our collegial discussions, in our informal conversations we show understanding which is richer than in our discursive texts. Third, the most profound lessons are not those which we are told ex cathedra by others, but those which we discover ourselves in interpreting diverse human practices and symbols - such as letters from Deans.

It follows that the letters reproduced in the paper are presented warts and all - sexist and other gaffes unexpurgated. I am grateful to my various colleagues and former students for their comments on the piece, and most importantly, for having given me the occasion to write the letters comprising “Academic Questions”. I only hope that it is faithful to their understandings and expectations. Before I launch into my prepared presentation, which incidentally, takes the form of yet another letter to now Professor Genevieve Martin, let me offer the standard disclaimer about my competence to giving this paper by means of a variation on the old 
joke about a retiring Dean's advice to a successor.

At the appointed date for passing on the reins of power, the former Dean hands the new Dean four envelopes, with the admonition: when things first get bad, open envelope \#l; when you feel you are losing control of the Faculty, open envelope \#2; when you get petitions demanding that you resign, open envelope \#3; and when even your family thinks you're becoming paranoid, open envelope \#4.

Sure enough, after the honeymoon period wore off, grumbling began to emerge in the Faculty. The new Dean timorously opened the first envelope. It said: Blame Me. So for the next year the new Dean criticized the previous Dean, explaining that all the Faculty's problems were the result of bad planning, and that soon things would get better. Well, as you know, they never do get better. After a second year of no salary increases, and a particularly high examination failure rate, both professors and students were in a vile mood. Figuring that this was the designated second occasion, the Dean opened envelope \#2. It said: Strike a Faculty Review Committee. This brilliant strategy calmed things down for another year or so. But then the Committee reported. Soon after, petitions calling for the Dean's resignation began to circulate. This was the occasion for envelope \#3. Inside was a note: Launch a Fund Raising Campaign for the Library — and name your severest critics as joint organisers. Once again the advice had the required effect. But, no stratagem lasts forever, or satisfies all constituencies. Some time later, the pressures of Deaning provoked the long-anticipated family crisis. Even the pet budgie stopped singing when the Dean came into the room. With trepidation envelope \#4 was opened. It said only: Prepare 4 envelopes.

Well I could stop now: scapegoating, committees, fundraising and shirking responsibility pretty well capture the pathologies of contemporary Legal Academia. But I won't stop here. Let me instead turn to the text I have prepared for delivery today. As I mentioned, it consists of yet another letter to now Professor Martin, this one written from Perth, ostensibly on July 14,1991 (that is, tomorrow).

July 14, 1991

Ms Geneviève Martin 
Faculty of Law

McGill University

3644 Peel Street

MONTREAL (QC)

CANADA H3A 1W9

FAX: 0011-1-514-398-4659

Dear Geneviève

No doubt by now you must be well established at McGill. I hope the move from Geneva didn't prove to be too difficult. I'm sorry that your work at the Swiss Institute of Comparative Law held you up till after we left on sabbatical. But, having missed your arrival in Montreal just gives me all the more reason to write regularly. Please keep in touch about how things are going with your research and course preparation.

Yesterday I presented my spiel on “Academic Questions” to an audience of about 120 law teachers from Australia and New Zealand. As I suspected it would, my paper and presentation drew a mixed reaction. Some in the audience were polite, but sceptical being rather more interested in getting information about the "careerist" aspects of legal academia: how does one get hired? what are the salaries? should there be a system of merit-driven increments? how do various promotion and tenure schemes work? what are the normal teaching loads for the different ranks? how much committee work is expected? what kind of research output is required? etc. I thought I had addressed most of these questions at least indirectly — by reproducing my hiring correspondence over the years. But, perhaps I should have dealt with them in a more familiar format, complete with the appropriate stylistic conventions and footnotes.

There were others, however, who seemed to find my presentation more congenial. These were probably those who had had the time to read and think about the paper in advance. Indeed, the themes of Academic Questions fitted in quite nicely with some of the other papers delivered at the Conference. Still others in the audience thought that the piece was just another example of American self-indulgent crap, spun off in a hurry for an easilybamboozled foreign audience. I guess I'm not well placed to speak 
to the "self-indulgent" charge, but you know from experience that the article was not just "spun off' in a hurry. I'm also a little offended to be lumped in with the "Americans" — as if Canadians can't also produce junk in their own right. Perhaps I should have written the bulk of the letters in French, or at least spiffed them up with a few recognizable Canadianisms, eh?

After the session I had several very interesting conversations with people from a variety of Faculties. Rather impolitely, I scribbled down their comments for use in the eventual Introduction to the formal paper. I've set them up as a series of propositions, which (playing to the “Academic Questions” theme) I've labelled "Model Answers". When I gave the paper yesterday I used a similar format, under the title "Practical Answers?", as a way of tying the ideas in the paper together. I had initially considered attempting to be cute by engaging the audience in a Socratic dialogue with a new series of academic questions. But then I remembered what happened to Socrates. So I decided not to "hide the ball”. Instead, like the paper itself I gave the answers without the questions.

Frankly, I had another reason for doing it this way as well. During my third year at Osgoode Hall, there was a "security leak" discovered just prior to my Commercial Law exam. The professor, at wits end for a new question, asked that standard fall-back as a substitute: "Compose an exam question which canvasses the principal issues in this course, and then answer it”. Being a bit of a smart-ass I wrote the following as my answer, convinced he'd have to give me an "A: "Compose an exam question which canvasses the principal issues in this course, and then answer it”. When the marks came out I got only a "C. Indignant, I made an appointment to see him to ask why. He replied: 'You've only answered half the question. To get an " $\mathrm{A}$ " you would have had to write the sentence twice - once to compose the exam question, and a second time to answer it”. A valuable lesson that was. It's very easy to be too cute by one-half.

So, here are my revised and corrected "Model Answers" to ten “Academic Questions”. I'd really be interested in finding out whether you think they bear any relationship to those I gave during our exchange of correspondence about your own recruitment to McGill. And please treat them like any "Model Answers" — not as 
exhaustive (or universal) truth in themselves, but as tentative (and contextualized) invitations to further inquiry.

First, whatever else it can aspire to be, law teaching is a job. No matter how idealized by people giving papers at academic conferences and by Deans, law teaching involves the performance of a number of specified tasks which can, at least theoretically, be grouped together under something called a "job description". Whatever else one does in exchange for a salary, there is a minimum (however slight tenure may have made that minimum) component to the job which must be met. Moreover, because law teaching is a job, it also has a boss. And the boss has a boss as well. Complex organizations like Universities are no less bureaucratic simply because their product is intellectual rather than material. In fact, given their amorphous character it is probably the case that Universities are more bureaucratic than the plant floor.

But, of course, a professorial position is also more than a job; it is an office, a role - with its own criteria for tenure and its own role morality. One is not being a wishy-washy liberal in claiming that “just doing your job isn’t good enough. I was struck in my conversations by the number of people who in all seriousness (that is, not metaphorically) took one or two extreme positions, saying EITHER: law teaching is not a job, it is wonderful - imagine getting paid to do what you'd do for free anyway; OR, law teaching is just like any other job -it's the same as a union sweat shop except that the Dean is the foreman. As is always the case, the truth lies somewhere in the middle.

Second, law teaching is a career, a vocation. It is not just casual employment, but demands a major commitment of energy and especially, emotion. Of course, it is not always a life-time enterprise. There are many casualties on the way to retirement. Some (but only a very few) take the form of denials of tenure; and even fewer flow from "dismissal for just cause" related to incompetence. Most are the result of an inability to cope with the ups and downs of daily living: the inevitable minor career disappointments; the personal frustration which comes from realizing that one is growing older faster than one is growing wiser; the (usually unfortunate, but sometimes unforgivable) indiscretions and transgressions which afflict any career. 
To see law teaching as a career means to recognize in oneself the play of overweening ambition, jealousy, greed, intolerance, anger, indiscipline and the "rather singular sin" of languid indifference (perhaps better known in its modern variants of idleness and sloth). It also means to confront alcoholism, drug dependence and depression with empathy and understanding. Finally to conceive law teaching as a career compels us to acknowledge and denounce repeated power-tripping, intentional insensitivity to others, and abuse of confidence (especially as this works itself out in sexual relationships with students and spouses of colleagues). Briefly, to see law teaching as a career means seeing it as a project worthy of one's commitment over a lifetime, regardless of how long one actually devotes to the endeavour.

Third, law teaching does not have a single model for its exercise. As with most things in life, there is no "one right answer". As my mother used to say to me after a squabble with my siblings: "Look Rod, you're not perfect. Neither are they. You should be glad they're not just like you. Even if I were perfection personified, I could think of no hell on earth worse than being surrounded by people just like me". Of course, the lessons of diversity and plurality are easily stated (and misunderstood) in the abstract. But they are lessons which (properly framed) must be and can only be learned in the living. Post-modernism can be parodied as a wonderful parlour-game; critics insisting that the law faculty is nothing more than a protective cocoon for speculating about "what might be”. But actually living a life which is contingent (that is, which is responsive to difference) demands passion and patience in the sense of the Latin patior. How many people who claim to be post-modernists do volunteer work in political organisations? How many even deign to make the despised liberal's usual "uncommitted" social contribution - a generous donation to the United Way? Law teaching is neither the abstract, hyper-rational ivory tower of the caricatured Academy, nor is it the nominalist, emotive, self indulgence of the Academy's internal critics. To say that there is no one model of law teaching, then, does not mean that anything goes. It means, rather, that whatever goes must in fact go. Difference is a doing (a committed practice) and not just a saying. In this sense Huey Newton was right: if you are not part of the solution, you are part of the problem. 
Fourth, law teaching commands its professors to see not only diversity in others, but also to recognize themselves in all their complexity. Those with only one sense of themselves, and hence only one agenda - be the agenda overtly political, like Law and Economics; be it socially transformative, like legal pluralism; be it cultural, like minoritarianism - usually avoid having to confront the conflicts, confusions and inconsistencies in their own lives. The commitment of law teaching does not demand that each one of us overtly embrace a metatheoretical stance which automatically reconciles each of these selves in a lexical hierarchy.

We owe it to ourselves and to our students to recognize these conflicts, and to attempt to work through their contradictions. Dismissing them as unworthy of attention is to dismiss ourselves as unworthy of regard. But, to require that we uniformly take one starting point, and impose this on all our other selves is both to assume that who we are is given as an anthropomorphic unit - i.e. we only have one body, therefore we must be one person - and to presume that we can have a meaningful critical position about ourselves which is external to us. The latter is a theological question that I, for one, am not competent to pursue.

I do think, however, that who I am in relation to others - as for example, parent, child, spouse, neighbour, friend, colleague — and who I am in relation to my genetic past -as for example, mostly white, mostly male, 42 years old, relatively healthy, tall, marfian and slender - and who I am in my social construction - as for example, legally trained, middle-class, protestant, english-speaking, and riven by self-doubt and guilt - is important to who I am as a law teacher. I am, emphatically, not just one of these things. This point was brought home to me in a humorous, but embarrassing way some years ago. At a conference on secured financing law in the early 1980s, a well-known Montreal practitioner, Yoine Goldstein, introduced me as follows: "It is a real pleasure for me to present Rod Macdonald, an old friend who I know quite well. I've known him as a child. I've known him as an adolescent. I've known him as an adult. Some times on the same day”.

Fifth, law teaching is both profoundly individualist and profoundly social. I concede that the image of the lonely professor working for years on a particular insight has an atavistic appeal. So too, that of the eccentric teacher who walks absent-mindedly to 
class, presents a brilliant synthetic stand-up lecture, and flees in horror at the prospect of having to deal with questions after class. But these are false images of individualism. Individualism in law teaching means seeking to be responsive to and to satisfy yourself: to have taught a class well; to have written, just once, something that appears to be insightful (if not true); to have believed, if only for a moment, that in a period of quiet reflection in one's office one has come to a clearer insight about who one might be. It is in these senses that law teaching is profoundly individualistic.

Of course, the obvious complement to this aspect of law teaching is its social side. How one deals with one's colleagues and students as people is fundamental. Brilliant scholars who are total creeps as people should cause us to rethink what we mean by brilliant scholars. Moreover, it is hard to conceive that any knowledge is individually generated. My own experience suggests that asking colleagues to read manuscripts and to discuss ideas about teaching, and serving on committees with them powerfully shapes what I know and how I know it. This is especially true of those with whom I disagree. A critical read by a theoretical opponent is worth at least as much as a sympathetic read by an intellectual ally. The community aspect of law teaching commands us to contribute to the work of others, and to treat their concerns almost on a par with our own.

But the social side of a law teaching career has a further extramural element. Universities exist in society. There is no greater abdication of responsibility than to claim that one is only concerned with the law as such, and not with how it affects people. Let me develop this idea negatively for a moment, before coming back to it in a more positive vein later in this letter. If one's obligation to society is just instrumental — to perfect legal dogmatics, one's social role is reduced to nothing other than offering succour and counsel to those who want information about a specific area of the law concerning which one professes expertise. And who are those who most often want such information? Law firms representing relatively pecunious clients. In my view, seeking the approval of, and financial pay-offs from, the practising profession is hardly a social aspect of law teaching with much to commend it.

Sixth, law teaching is a lesson in personal vulnerability. Whether, before one's class, before one's peers in published pieces, 
or before the public to whom one tries to be responsive, there can be no self-protective "petitions of authority or expertise". When a speaker predicates the credentializing phrase "As a ..." with an epithet which denotes expertise (along the lines: "as a family law scholar, ...”) or with other claims to special attention (along the lines: “as an ex-Dean ...”), rather than with a word which implies a self-critique of one's partiality of perspective (along the lines: as a traditionalist ...”), one should ignore the lesson being proffered.

Being personally vulnerable also means not hiding behind purple prose, obscure generalities, third person attribution or the sham of ideological neutrality. In the University, objectivity can mean nothing more than to rest one's position on the "best" arguments one can find, knowing that these may ultimately prove illusory. But a qualified objectivity is not at the same time a license for inculcation. This is especially true in the classroom. Those who use the podium as a political platform forget the extent to which their own ideas are, themselves, a product of ideology. The University is ideological; the law faculty more so; there is no ideological critique of law which is also not internal to oneself.

Neither can we conceal indoctrination behind the mask of “objectivity” or even "not taking a position”, nor can we conceal indoctrination behind the mask of academic freedom. To be vulnerable means to invite challenges to one's structure of belief, not to make either the naive realist claim that "that's the way it is" of the obverse non-cognitivist claim that " $\mathrm{X}$ is the $\mathrm{Y}$ position on the question". In other words, just because we strive for a "clean" truth doesn't mean that we can't or shouldn't recognize and confront our own commitments. All critique is, in this sense, ad personam.

Vulnerability also means not taking yourself too seriously. There is an old story about the child who comes home from school one day and tells his parent: “School's terrible. I'm not going to go tomorrow, and I've got two good reasons. First, all the students hate me; and second, all the teachers hate me". To which the parent replies: 'You are going to school today, and I've got two good reasons. First, you're forty-two years old and second, you're the Dean”.

Seventh, law teaching is about education. If I remember it properly, our word education is derived from the Latin educere to lead (or draw) out. Students and professors are not empty vessels 
into which knowledge is poured, to be retained for future deployment in appropriate circumstances. Of course, they are also not omniscient beings, possessed at birth of infinite wisdom that only needs to be set free of the constraints imposed by a repressive society. Each of us, in Eliot's words "knows and does not know". Education is about the conditions of knowledge; especially the conditions of self knowledge. For this reason, institutional education such as that undertaken in law faculties must be primarily directed to knowledge rather than information.

If I am right about this, then law teaching is, above all else, about the education of the law teacher. It is a context in which we are educated by the attempt to educate others. "Stupid" questions are often more valuable than "good" questions. Of course, some questions are just "stupid”. But many questions are called "good” only because they comfortably fit the logic of the discourse being undertaken - just pushing that logic a little further. Seen in this light, some questions are "stupid" for no reason other than that they are uncomprehending of that "given" logic. The real teacher will take the trouble to locate the sources of the incomprehension so as to uncover the inarticulate premises which ground the conventional logic; and to uncover these premises is the threshold step to holding them up to examination. In this way, the endeavour of education (of direct interaction with students) educates us more richly than the acquisition of book learning.

For both professors and student, then, “wrong” answers are infinitely more valuable than "right" answers. A well-crafted examination ultimately tests the teacher as much as the student. A thoughtful correction and exam review process teaches the examiner as much as the examinee. Except where a student treats an exam as nothing more than a "barrier to market entry" and where a professor is burdened with a correction load in the hundreds, each is being drawn out by the educational exercise.

Eighth, law teaching is about practising what one preaches. One of the great advantages of the University is the opportunity it gives each of us to take responsibility for how we live our professional lives. In our relationships with our colleagues and students we are engaged in building an organization (or community) and in administering a normative order. This is, indeed, what law is all about -be it law at the level of voluntary associations, employment 
organisations, municipalities, states, or the world community. Unfortunately, however, many of us let the opportunity pass us by, and as a consequence forfeit our claim to the moral high ground.

Two such opportunities are worth noting here. The first is the chance we have each year to recruit new students; the second is the opportunity to recruit new colleagues. Let me focus on the latter. How often do we simply take our cue from "past practice”? While I do not want to be understood as saying that Universities should hire "any old person" I think it is important to recognize that many of the standards it currently imposes are neither central to its mission nor inviolate. If we believe that law is grounded in social practice then ought we not try to make an effort to enrich our own practices so as to gain a better perspective on society?

I greatly dislike the spin which has recently been given by the liberal press to the words "affirmative action" and "equal opportunity”. "Affirmative action” is not about just co-opting target constituencies into existing structures. We would be more honest were we to not hide behind a formula, but overtly to embrace a policy of "intellectual heterogeneity" and personal "continuing education”. Why should we not each maintain our educational pursuits through our colleagues and through our interactive practices? The liberal rhetoric of affirmative action suggests that the new recruits are to be bootstrapped into an existing order which, it is hoped they will then internalize. Is it any wonder that new recruits then either become zealots for the existing institutional order or become marginalized by having to reject vigorously the "received (and unassailable) wisdom" of their new colleagues?

Practising what we preach will occur only when heterogeneous recruitment is designed to educate those already present - to move their boundaries and to change the structure of their "received wisdom". Only when existing practices are open to change and only when reason becomes a medium of exchange rather than a currency of entrenched political action committees will we be affirming what we preach. Of course, not all cleavages are equally important; not all differences demand special concern. But only by rejecting uncritical pluralism will we be genuinely educated by our embrace of difference.

Ninth, law teaching is addictive; and all addictions are destructive. The addiction of law teaching can occur in several 
ways, but it has two main variants. First, it can induce us to spend enormous amounts of time at it. This is time we take away from our families, away from the many other selves (carpenter, canoeist, cinemaphile, musician, gardener, gourmet chef, science-fiction buff) who we are, and away from pursuing social commitments which take "time” and "energy", and not just money. Certainly law teaching is an end in itself. But we need constant reminding that it is not our only end (and not necessarily even our most important end). While we can never be "off-the-job — be this in the corridors of the faculty, at lunch, on the bus, or even at home - we must always make sure that the job is part of us, rather than us being a part of the job. This, I guess, is partly what I was trying to hint at by putting all your student-related past correspondence into the “Academic Questions” paper.

Law teaching is also addictive in that it can be self-indulgent. It is easy to think that what we do as teachers (or what we write as scholars) is terribly important in some transcendent sense. It is equally easy to think that one good legislative or judicial effort will "solve the evils of the world" and that we have the crucial role to play in moving society from a state of nature to a state of grace. Humility has never been the long suit of the jurist. Narcissism and hubris have rather tended to dominate. It is not, of course, that most of us consciously go about creating in our oeuvre the changing "picture of Dorian Gray" which protects us from seeing our true selves. No, the curse of self-indulgence is that in taking ourselves too seriously, we become a parody of ourselves, incapable of doing anything except reproducing both our work and ourselves, over and over again.

Tenth, law teaching is not a monopoly. As full-time law teachers in law faculties we have never had, nor are we ever likely to have, a monopoly either on legal education or on legal knowledge. Neither within the Academy, nor outside its precincts, can we claim an exclusive writ. Other faculties in the university, we have recently discovered, know something about law. So (surprisingly to some of my colleagues) do the bench and bar. Most importantly, so also do ordinary citizens.

Within the University, the assault on the very notion of law as a distinct discipline has shaken the legal education establishment. There are those who now claim (and I guess that I am one of them) 
that the certain result of taking postmodernism seriously is the reintegration of the humanities - history, literature, political theory and economy, philosophy, mathematics, and law, for example and the end of the false disciplinary boundaries which are the curse of positivism and its social sciences off-spring - psychology, sociology, anthropology, political science, and linguistics, for example. If this is so, then we have an obligation to expand our intellectual horizons, not contract them. Only the dilettante sees the pursuit of new horizons as a simple gloss on the "positive" law of treaties, constitutions, statutes, regulations, cases, collective agreements, and contracts, rather than as an invitation to new ways of knowing.

Outside the university we also have no monopoly. Those who practice law invariably know the so-called "hard data" better than we do. Not just the data about whether the form is green or yellow, or about whether practice court is Room 3.01 or Room 3.02; they also know what regulations are in the works, what judgments are coming down, and which court is likely to decide which case which way. This practical knowledge is, properly understood, legal knowledge - even if it is knowledge we do not possess. As law teachers we must recognize what we can do well, and what we cannot. Society's resources are too precious to misinvest in having us simply "practice law by teaching it”.

Finally, we have no monopoly on legal knowledge vis a vis the citizen. Law teachers, other university professors and the practicing profession are together not even oligopolists. The presumption of those who assert otherwise can only rest on a false understanding of normativity, which reduces law to simply that which is institutionalised, and which excludes the normative practices of citizens from law's empire. As you know from our work together on the Access to Justice inquiry, I think that a rich and complex practice of justice resides more in the implicit and inferential normativity of everyday human interaction than it does in the consciously constructed explicit and canonical normativity of legal professionals.

Our challenge as law teachers, then, is not to claim a monopoly on legal knowledge and to define our subject in a way that marginalizes other people. It is to develop an understanding of law and law teaching that embraces the insight of others, while at the 
same time recognizing and valuing those talents and insights that we do have. Paraphrasing the Talmud, I would conclude: If we are not for our own understandings, who will be for them; if we are only for these understandings, who are we.

Well, that's it. Ten very incomplete "Model Answers" to ten “Academic Questions”. But just in case you think I am trying to set up this epistle as a second-millennium Ten Commandments, let me add a further point. I might be all wrong about my purported answers. Not only partly wrong, but all wrong. I certainly don't feel now the same way about these issues as I did when I started teaching fifteen years ago (let alone twenty years ago when as an aspiring student politician I wrote a tract for the Osgoode Reform Coalition on the role of the law teacher). I don't even feel the same way I did before I became Dean, or an ex-Dean.

Will I hold to these beliefs when my children are seeking admission to some restricted enrolment programme at a University (should they choose to do so)? or when they are on the market for employment? or when they are asked to pay a larger part of the cost of what is now state-subsidized legal education? Will I hold to these beliefs twenty years from now when I'm faced with the prospect of retirement? I honestly can't say for sure. More to the point, even now I'm not certain about the value of the answers I'm giving. Teaching and writing are acts of faith; and all true faith is grounded in self-doubt. So, to condition everything that I've said so far, let me make an eleventh (and perhaps most important) point. Law teaching is deeply about self-doubt.

Please let me know what you think of all this. I hope I'm not turning into a modern Ptolemy spinning epicycles on epicycles, and trying to capture a truer glimpse of a picture by fiddling with the details of a model which is just plain wrong from the outset. I also hope that, having said my post- Decanal piece about Legal Academia, I will now have the good judgment to keep quiet. Thanks again for all you help in preparing the initial paper. Best wishes for the coming year. I'll write again soon.

Yours sincerely, 
* McGill University, Montreal, Canada. Paper presented at the. 46th Annual Conference of the Australasian Law Teachers' Association, held at the University of Western Australia, July 13, 1991. The present paper makes reference to and draws upon a series of letters written by a Dean to a candidate for appointment, including a number of other letters and memoranda addressed to that candidate during the years she was a student. All these letters were reproduced in the ALTA Conference Materials. 63 1992. (1992) 3 Legal Educ $\operatorname{Rev} 61$. 